\title{
INVESTIGATION OF THE USAGE OF PALM OILS WITH THE AIM OF INSULATION IN HIGH VOLTAGE POWER SYSTEM EQUIPMENTS
}

\author{
Nihat Pamuk
}

Original scientific paper

Power system equipment have conventionally used mineral oil for insulation and cooling. The preferable alloy material has to be generated with good chemical and electrical features. However, recent case has indicated the shortcomings of these fluids where they have poor characteristics particularly at fire and flash point and most significantly poor dielectric malfunction voltage. The most critical of these deficiencies is the disability to meet up with the environmental and health laws. Further, they are not organic and hence not biodegradable. In this study, natural palm oil and its derivatives have been studied in attempt to discover an environmental friendly insulating fluid. Patterns such as crude and refined palm oils were chemically and electrically tested and comparisons were made with the mineral oil. Electrical tests such as the malfunction voltage, power factor and resistivity were pursued. Besides that, chemical characteristics such as water content, kinematic viscosity, moisture content of the alloy, flash point, density, pour point, corrosion, neutralization value and dissolution of gases were also being investigated. Results from the test laboratory studies have indicated that the natural palm oil has preferable chemical and electrical features as compared to the existing mineral oil for power system equipment insulation.

Keywords: electrical breakdown stress; interfacial tension; mineral oil; palm oil; power factor

Istraživanje o uporabi palminih ulja za izolaciju opreme energetskog sustava velike snage

Izvorni znanstveni članak U opremi energetskog sustava uobičajeno se koristi mineralno ulje za izolaciju i hlađenje. Preferirani legirni materijal mora imati dobre kemijske električne karakteristike. Međutim, nedavni je slučaj ukazao na nedostatke tih fluida i loše karakteristike naročito kod točke paljenja i plamišta, i najvažnije, na slabi dijalektrički napon. Njihov najbitniji nedostatak je nepoštivanje zakona o zaštiti zdravlja i okoliša. Nadalje, oni nisu organski i stoga nisu biološki razgradivi. U ovom radu, prirodno palmino ulje i njegovi derivati proučavani su kako bi se pronašao izolirajući fluid bez loših posljedica za okoliš. Uzorci nerafiniranog i rafiniranog palminog ulja kemijski su i električki ispitani te uspoređeni s mineralnim uljem. Provedena su električna ispitivanja kao na pr. neodgovarajući napon, faktor snage i otpornost. Osim toga također su ispitivane kemijske karakteristike kao što su sadržaj vode, kinematički viskozitet, sadržaj vlage legure, plamište, gustoća, temperatura tečenja metala prilikom lijevanja, korozija, vrijednost neutralizacije i rastvaranje plinova. Rezultati laboratorijskih ispitivanja pokazali su da prirodno palmino ulje ima poželjnija kemijska i električna svojstva u usporedbi s postojećim mineralnim uljem za izolaciju opreme energetskog sustava.

Ključne riječi: električni probojni napon; faktor snage; mineralno ulje; naprezanje u dodirnoj površini; palmino ulje

\section{Introduction}

Power transformer is one of the crucial part devices in the power system. Besides, power transformer life governance is an important topic in the modern power operation system. Oil filled power transformer technology has been used for more than 50 years [1]. Impurity is the principal factor that diminishes the insulating efficiency [2]. The maintenance of the insulation system largely detects the extent of power transformer's life. Future power transformers will no suspicion have raised capacity and size and their design may call for the use of new elements [3]. Power transformer may operate at higher temperature in turn demand power transformer oils of greater stability. Power transformer oil manufacturers want to supply the client with oil that gives good efficiency in real field of operations [4].

Power transformer oil or insulating oil is usually a highly refined mineral oil that is decisive at high temperature and has perfect electrical insulating characteristics. The oil assists to cool the power transformer. Because it ensures part of the electrical insulation between interior live parts, power transformer oil must remain decisive at high temperatures for an extended time. Thenceforth long time ago, petroleum based mineral oils were used as fluid insulating elements $[3 \div 5]$. At the present time, the oils are commonly used as insulation for power transformer or other high voltage devices. This is because the insulating oils have perfect dielectric characteristics such as low dielectric losses, high electric field strength and good long term efficiency [6]. However, owing to the environmental consideration, the oils are considered to be replaced with more environmentally friendly liquid insulating elements such as palm oil, vegetables oil and others.

Many researchers are now investigating novel kinds of insulating elements, which are generally organic kinds and attained from the native [4]. So as to get new insulating oil for the power transformer insulation medium, tests have been conducted to provide the characteristics of this new element follows the standard demand. The tests are to be associated to the function of the oil which is fulfilling some of the meant needs of the user. When oil is complementary section of the power transformer, its attitude can be associated to its molecular combination and physical characteristics. There are some materials which impact on its attitude such as dielectric strength, moisture, air content and other foreign factors. The most basic demands of the power transformer oil are the electrical characteristics and the thermal attitude [7].

\section{Properties of palm oil in power system equipment}

The oil in a power transformer has several functions, the most important of which are of course insulation and cooling. Another function is to carry information about the condition of the active parts of the power transformer. Based upon the finding for the insulating liquid, the alternative should have the feature of cooling the electrical equipment. Along with this line, the plant based 
oils are selected. Resent research work and industrial research and development have come up with idea that vegetable oils termed as biodegradable oils can find industrial applications [8]. Vegetable oils do not include any sulphur, aromatic hydrocarbons, metals or crude oil residue [3]. The lack of sulphur means a reduction in the formation of acid rain by sulphate emissions which can create sulphuric acid in our atmosphere [6].

Chemical combination is important for the vegetable oil which entirely qualifies as a dielectric liquid. Crude vegetable oils extracted from oil seeds have a dark colour and include solid constituents such as fibres, proteins and liquid [9]. Both fats and oil are triglyceride esters of fatty acids, but fats include a relatively high percentage of saturated triglyceride and would freeze to solid below room temperature [10]. Inherently, the palm oil is defined as stabilized oil owing to its chemical combinations. As such it can be used in most food applications without hydrogenation thus declining manufacturing costs by as much as $34 \%$. So as to investigate the efficiency of palm oil as a novel insulation power transformer, there are several patterns of palm oil and its derivatives that have been used, such as crude palm oil (CPO), refined palm oil (RPO), crude palm oil category 6 (CP6), crude palm oil category 8 (CP8) and crude palm oil category $10(\mathrm{CP} 10)$. Mineral oil is also tested to be as a reference with the palm oil patterns and its derivatives.

\subsection{Dielectric dissipation factor (tan delta / power factor)}

This is a parameter that will always be found in a power transformer oil specification. The loss angle depends on the amount of ions in the oil. A normal degree of refining always gives a low value for this parameter, but it is very sensitive to contaminants. So big is the effect of molecules of this type that just a few parts per million (ppm) will destroy the tan delta. Water itself does not affect this property, but can participate in forming stable complexes with oxidation products, or with other impurities to give high tan delta values. When oil starts to deteriorate, an increase in tan delta can be found at the beginning of the oxidation process, followed, after a time by a decrease. Metal complexes produced have a strong polarity and a high content of ions, and so this causes an increase in dielectric loss. This peroxide will be decomposed into new radicals, forming oxidation products, with a lower tan delta. After the initial decomposition stage, oxidation products, such as acids and esters form, causing the tan delta to increase again.

Normal value for an oil as manufactured is $<0,001$ at $90{ }^{\circ} \mathrm{C}$ and 50 to $60 \mathrm{~Hz}$. In some specifications power factor is used instead of tan delta. The difference is little at low measured values. Power factor testing suitability is performed with the BS5737 standards [11]. The experimental establishment contains the usage of capacitance and power factor test set and high voltage supply and control. The equipment used is the alternative current (a.c.) bridge Type M-oil liquid insulation test set as shown in Fig. 1. The voltage supply was increased step by step from $2 \mathrm{kV}$ until $10 \mathrm{kV}$. Each of the voltage supplied is implemented at 10 times per second.

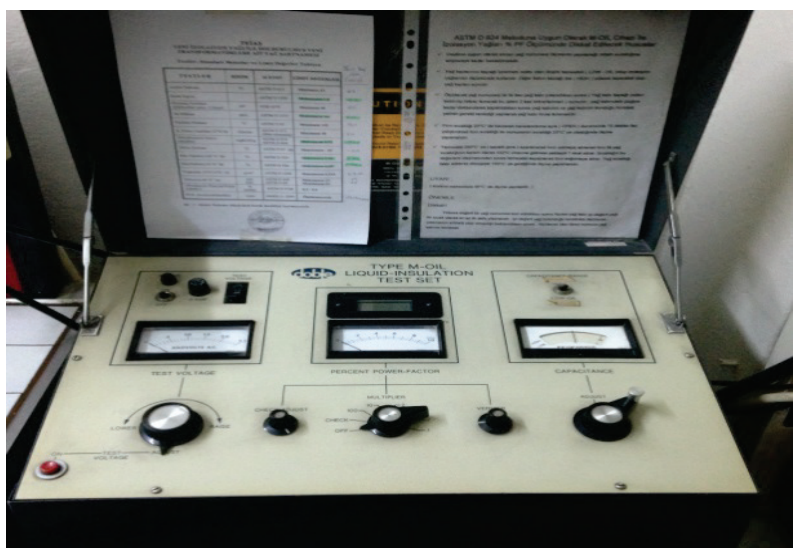

Figure 1 Capacitance and power factor test set

\subsection{Electrical breakdown voltage (A.C.)}

The electrical breakdown voltage testing suitability was performed with the BS148 standards [12]. The experimental establishment contains the usage of high voltage power transformer, measuring capacitors, connectors and accessories and the measuring sets. The experiments were conducted at the high voltage test laboratory and the measuring set is shown in Fig. 2 and Fig. 3 respectively. The electrical breakdown voltage supply was implemented to the test patterns using the high voltage creating and measuring systems.

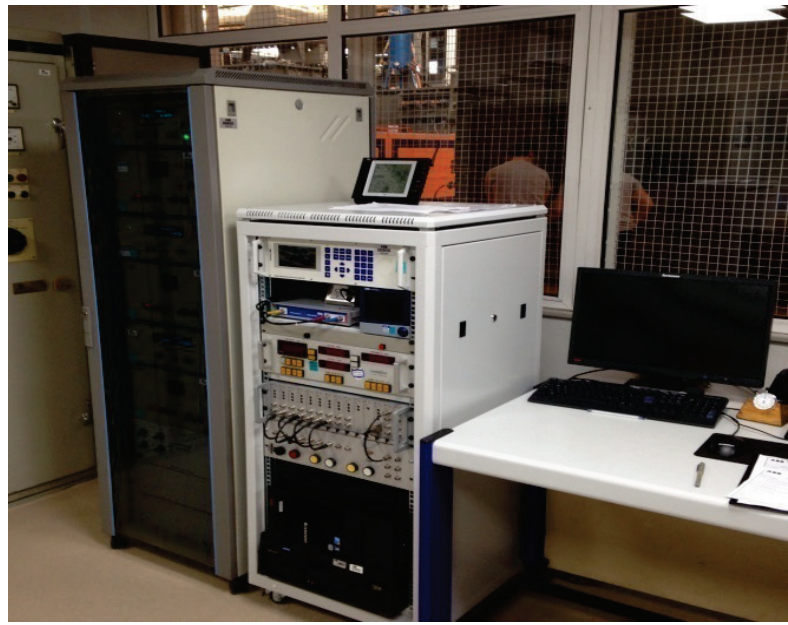

Figure 2 High voltage test laboratory

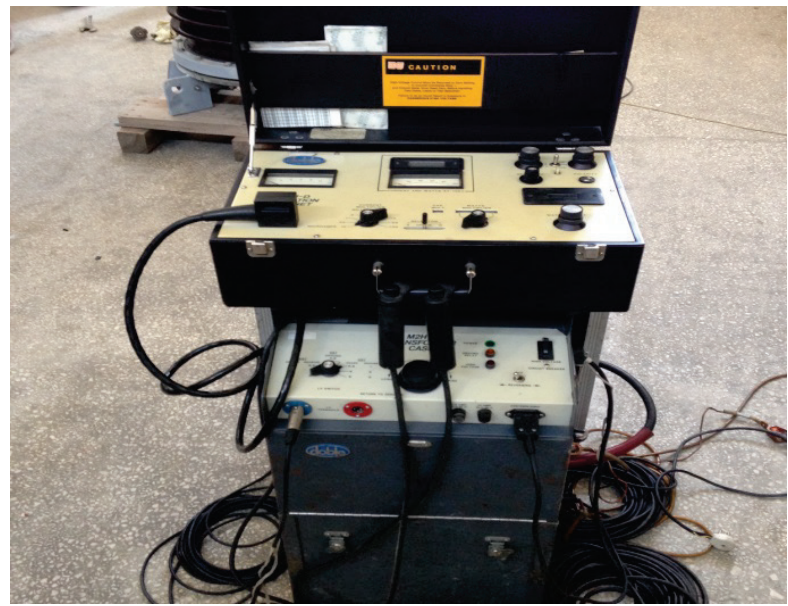

Figure 3 Measuring set of electrical breakdown voltage 
The electrical breakdown voltage test property is very complex and the measured value depends on particle content, type of particles, water content and the test method used. In this method the electrodes are spherical or hemispherical at a distance of 2,5 $\mathrm{mm}$ and the voltage is increased by $2 \mathrm{kV} / \mathrm{s}$ until breakdown occurs. Even low refined oil may have a high breakdown voltage, so this method tells us nothing about the refining of the oil. The removal of water and particles can give a breakdown voltage of more than $70 \mathrm{kV}$ to any oil. The IEC specifications have over $30 \mathrm{kV}$ as a minimum level [13], and if the result is lower than this, all it requires is a simple degassing treatment to raise breakdown to more than $50 \mathrm{kV}$. The amount of particles might also be influenced by the carbonisation of oil molecules that occurs in partial electric discharges. The amount of particles formed is related to the result of the carbon residue analysis of the base oil, and here the naphthenic oils have an advantage over the paraffinic oils.

\subsection{Neutralization value}

In well-refined oil the neutralization value must be less than $0,01 \mathrm{mg} \mathrm{KOH} / \mathrm{g}$ oil, but because this method has a repeatability of 0,03 , the minimum requirement is less than 0,03 . This level, however, is too high to give any guidance on the property of the oil. Well-refined, noncontaminated oil must have a target value below 0,01 . Fig. 4 indicates measuring set of neutralization value.

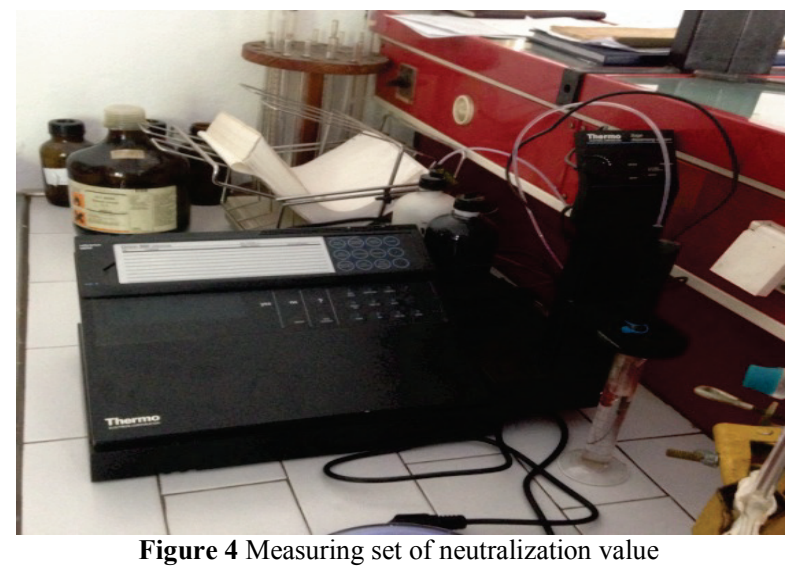

\subsection{Kinematic viscosity}

The kinematic viscosity of oil is important for the cooling of the power transformer; the lower the viscosity, the better the cooling. Increasing temperature reduces viscosity, and a small change in viscosity with temperature means a high viscosity index, while a big change indicates a low index. In lubrication applications, oils with high viscosity index are recommended. A low viscosity index is preferred for cooling, because lower viscosity is required at operating temperature. It is never an advantage to use high viscosity oils, because the higher the viscosity the worse the cooling properties. This gives higher working temperatures, higher losses, resulting in faster deterioration of the oil and the paper. Naphthenic oil is therefore preferable. The aim of performing this experiment is to know the flow ability of the oil patterns at a temperature of $40^{\circ} \mathrm{C}$ and $100^{\circ} \mathrm{C}$. Oils with viscosities of around $9 \div 10 \mathrm{~mm}^{2} / \mathrm{s}$ are those which are mainly used today. Fig. 5 indicates kinematic viscosity set which is used at $0{ }^{\circ} \mathrm{C}, 40^{\circ} \mathrm{C}$ and $100^{\circ} \mathrm{C}$. Viscosities of some of the oil patterns were also detected using a glass capillary viscometer.

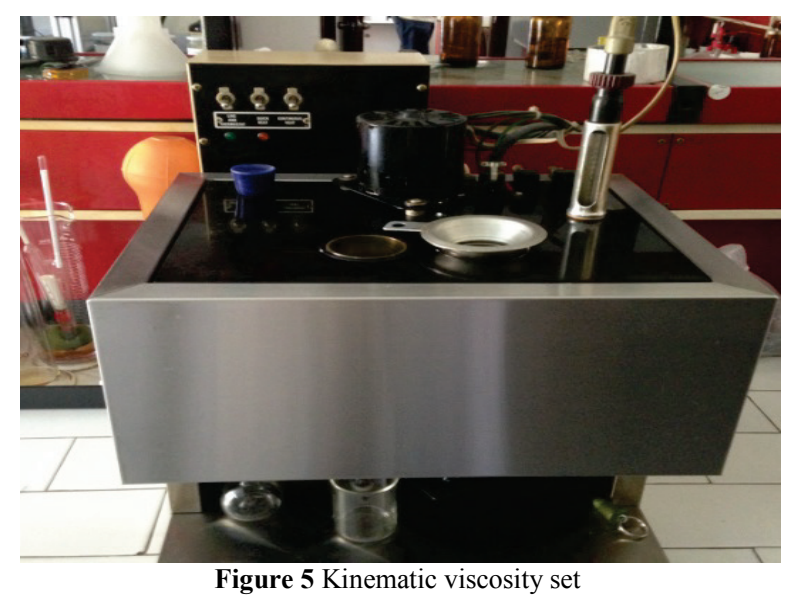

\subsection{Flash point}

Flash point is detected by referring to the standard ASTM D93 by using Pensky-Martens Closed Cup Tester (PMCC) as shown in Fig. 6. ASTM D93 is referenced as an admissible test method for the classification of combustible liquids. The Pensky-Martens Closed Cup Tester is used to detect the flash point of viscous or film forming liquids and liquids with a flash point greater than $93{ }^{\circ} \mathrm{C}$. The flash point of oil is specified for safety reasons. In the three IEC 296 grades, the following flash points are stipulated. (Flash point $\mathrm{PM}{ }^{\circ} \mathrm{C} \geq 140{ }^{\circ} \mathrm{C}, \geq 130$ ${ }^{\circ} \mathrm{C}, \geq 95{ }^{\circ} \mathrm{C}$ ) The flash point depends on the light part of the oil and is extremely sensitive to contaminants from lighter oils such as gas oil or gasoline. Even though both methods yield relatively poor reproducibility, the closed cup method is preferred because it provides better repeatability.

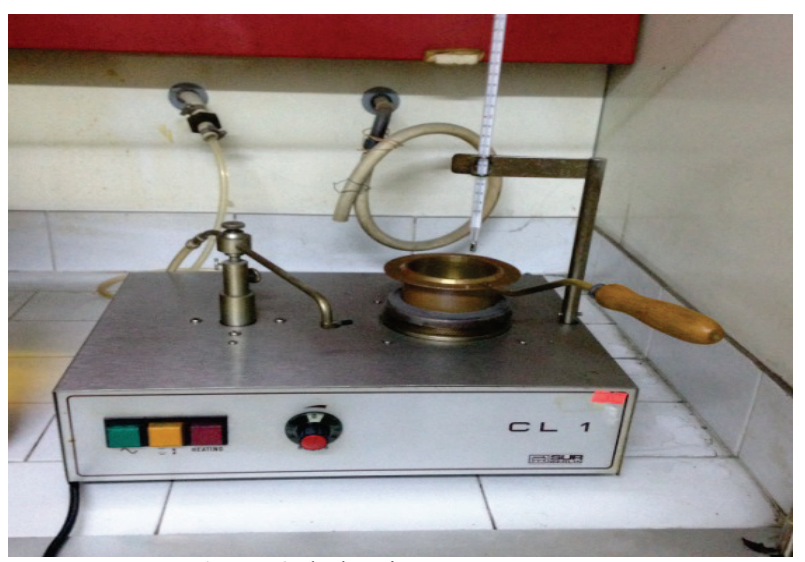

Figure 6 Flash point measurement set

\subsection{Density}

In cold climates it is important to specify oil density to avoid the occurrence of ice floating in the oil at low temperatures. This can occur when there is free water present in not energized transformers and which can cause failure during start up. Oils with high aromatic content 
have higher density than oils with more naphthenic and paraffinic molecules. The density decreases with increasing temperature and the standard coefficient $0,00065 /{ }^{\circ} \mathrm{C}$ is used for calculating the density at other temperatures than those measured. This coefficient will vary somewhat with the different oils, depending on the structure and degree of refining. Density measurements were managed using glass hydrometer method by referring to standard ASTM D1298. This method was also being used to detect the relative density, or API gravity of crude petroleum, petroleum products, or mixtures of petroleum and nonpetroleum products normally handled as liquids and having a Reid vapour pressure of 101,325 $\mathrm{kPa}$. Density measurement set is shown in Fig. 7.

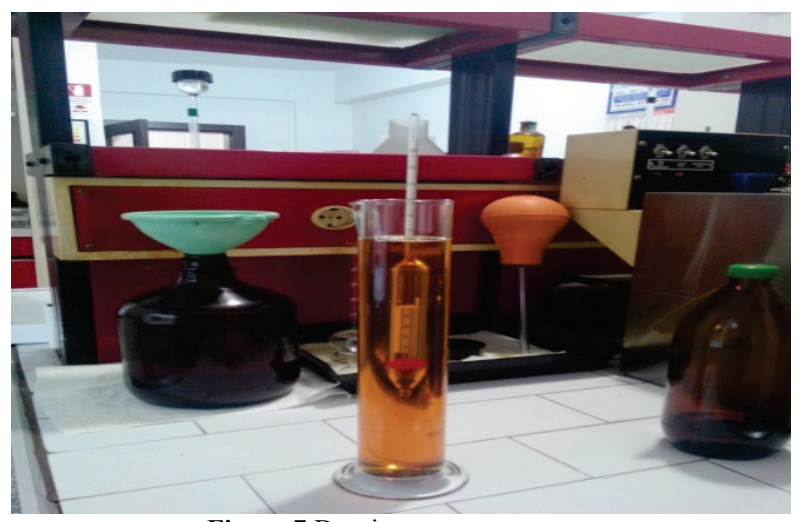

Figure 7 Density measurement set

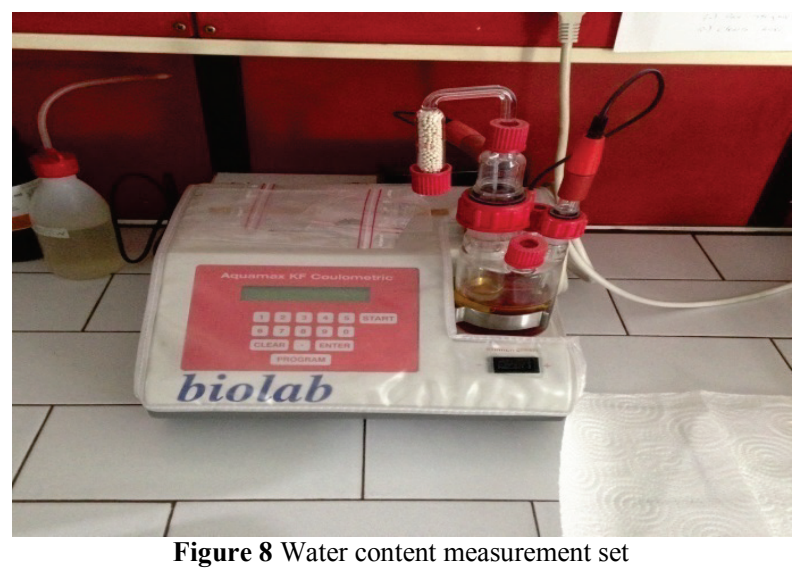

\subsection{Water content}

The solubility of power transformer oil in water directly depends on temperature and number of aromatic molecules present. It is difficult to maintain low water content especially in generator transformers as they are located in high humidity area near to water source, needed for power-plant cooling. Just super heating the oil does not reduce the water content as water solubility increases with temperature. Oils with high temperature foam excessively due to evaporation process. During oxidation of the oil, water is formed as an oxidation product, in which case it is an advantage for the oil to have high solubility, so that there will be no free water. Oils with high water content may foam when they are degassed. This is not real foam. Real, stable foam can be found in contaminated systems. As a general rule, clean liquids do not foam. The water content of an oil pattern can be measured using the water content measurement set as shown in Fig. 8.

\subsection{Interfacial tension}

The interfacial tension test measures the strength of the interface between oil and water. The interfacial tension depends on the polar groups in the oils, whilst tan delta $\left(90{ }^{\circ} \mathrm{C}, 50 \mathrm{~Hz}\right)$ tells something about the content of ionisable contaminants. This property of the oil depends upon the polar molecules and impurities in the oil. The value of interfacial tension for normal oil in good service condition usually lies between 45 and 50. The new transformer oil has interfacial tension value of 40 . The interfacial tension measurement set is shown in Fig. 9.

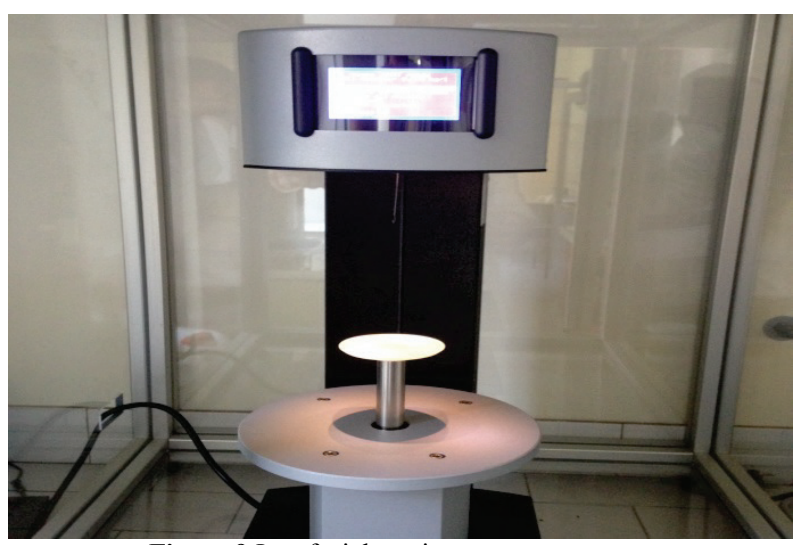

Figure 9 Interfacial tension measurement set

\subsection{Particles}

Oil treated with modern refining techniques has low particle content, but as soon as it is transported and stored this content increases. By passing the oil through a degassing unit, which contains a particle filter, the particle content will be reduced to an acceptable level. If the oil is circulated through the power transformer and a degassing unit, it cleans the power transformer from dust and loose cellulose particles. Particles measurement set is shown in Fig. 10.

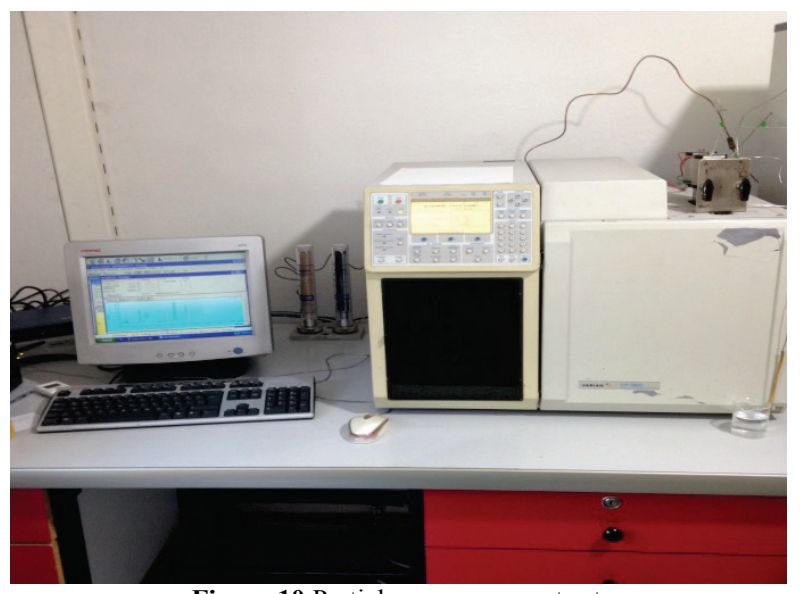

Figure 10 Particles measurement set

\subsection{Dissolved gases}

There are several gas analysis methods used today for predicting the type of fault occurring in the power 
transformer oil. Gas space and power transformer oil equivalents are used to compare results of gas analysis (TCG Total Combustible Gases) with the results from analysis of gas dissolved in the oil (TDCG Total Dissolved Combustible Gases). The results are then compared from gas space to dissolved gas in oil. The result is compared to predefined values to predict the condition and to determine the type of fault which has occurred in the power transformer. So as to estimate the situations of power transformer oil insulating material to prevent future breakdown problem the dissolved gas analysis was performed. The dissolved gas analysis was done by using Gas Chromatography Set as shown in Fig. 11. Oil patterns are to be taken into $50 \mathrm{ml}$ glass syringe with 2 way stopcock.

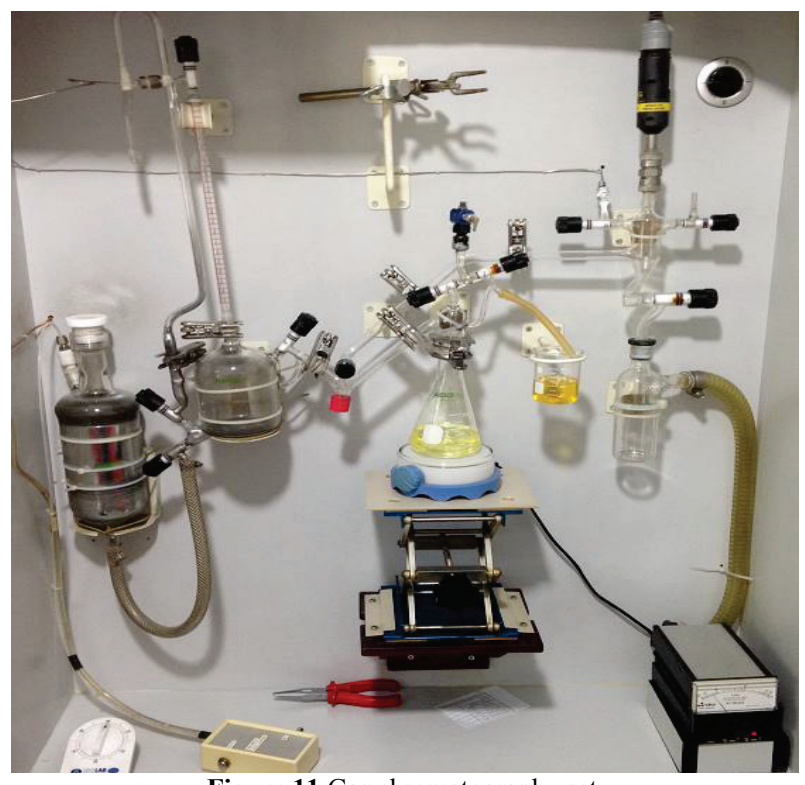

Figure 11 Gas chromatography set
The most extensively used method for evaluations of gases are Doernenburg and Rogers gas proportion method [14].

The gas proportion is used to show the type of breakdown assigning the cause of fault or failure during analysis. These methods are based on thermal deterioration and use a number of proportion criteria of certain combustible gases found in power transformer for fault type analysis. These five proportions are as follows:

- Proportion $1\left(\mathrm{P}_{1}\right): \mathrm{CH}_{4} / \mathrm{H}_{2}$

- Proportion $2\left(\mathrm{P}_{2}\right): \mathrm{C}_{2} \mathrm{H}_{2} / \mathrm{C}_{2} \mathrm{H}_{4}$

- Proportion $3\left(\mathrm{P}_{3}\right): \mathrm{C}_{2} \mathrm{H}_{2} / \mathrm{CH}_{4}$

- Proportion $4\left(\mathrm{P}_{4}\right): \mathrm{C}_{2} \mathrm{H}_{6} / \mathrm{C}_{2} \mathrm{H}_{2}$

- Proportion $5\left(\mathrm{P}_{5}\right): \mathrm{C}_{2} \mathrm{H}_{4} / \mathrm{C}_{2} \mathrm{H}_{6}$

Doernenburg method uses the proportion 1 and proportion $4\left(\mathrm{P}_{1}-\mathrm{P}_{4}\right)$. For the diagnosis to be valid, the gases have to be present in important levels. Roger method uses the proportion 1, proportion 2, and proportion $5\left(\mathrm{P}_{1}-\mathrm{P}_{2}-\mathrm{P}_{5}\right)$. This method does not depend on specific gas concentrations from the power transformer for diagnosis to be valid.

\subsubsection{Doernenburg proportion method}

All power transformers produce gases even at normal operating temperatures and conditions. Any abnormality in gas producing tendency within a power transformer operation can give an analysis of fault and type of breakdown. The breakdown may be thermal or electrical.

Generally weekly gas analysis is recommended after start-up of new power transformer, followed up by yearly interval of normal operating power transformers. The Doernenburg method is used to predict the three types of faults. This method utilizes gas concentrations from proportion 1, proportion 2, proportion 3 , and proportion 4 . Table 1 describes the relation between proportions and type of breakdowns [14].

Table 1 Comparison between proportions and types of breakdowns for Doernenburg method

\begin{tabular}{|c|c|c|c|c|c|c|c|c|}
\hline \multirow{2}{*}{ Type of Breakdown } & \multicolumn{2}{|c|}{$\begin{array}{c}\text { Proportion } 1\left(\mathrm{P}_{1}\right) \\
\mathrm{CH}_{4} / \mathrm{H}_{2}\end{array}$} & \multicolumn{2}{|c|}{$\begin{array}{c}\text { Proportion } 2\left(\mathrm{P}_{2}\right) \\
\mathrm{C}_{2} \mathrm{H}_{2} / \mathrm{C}_{2} \mathrm{H}_{4}\end{array}$} & \multicolumn{2}{|c|}{$\begin{array}{c}\text { Proportion } 3\left(\mathrm{P}_{3}\right) \\
\mathrm{C}_{2} \mathrm{H}_{2} / \mathrm{CH}_{4}\end{array}$} & \multicolumn{2}{|c|}{$\begin{array}{c}\text { Proportion } 4\left(\mathrm{P}_{4}\right) \\
\mathrm{C}_{2} \mathrm{H}_{6} / \mathrm{C}_{2} \mathrm{H}_{2}\end{array}$} \\
\hline & Oil Dissolved & $\begin{array}{c}\text { Gas } \\
\text { Space }\end{array}$ & $\begin{array}{c}\text { Oil } \\
\text { Dissolved }\end{array}$ & $\begin{array}{c}\text { Gas } \\
\text { Space }\end{array}$ & $\begin{array}{c}\text { Oil } \\
\text { Dissolved }\end{array}$ & $\begin{array}{c}\text { Gas } \\
\text { Space }\end{array}$ & $\begin{array}{c}\text { Oil } \\
\text { Dissolved }\end{array}$ & $\begin{array}{c}\text { Gas } \\
\text { Space }\end{array}$ \\
\hline Partial Discharge & $<0,1$ & $<0,01$ & \multicolumn{2}{|c|}{ Not important } & $<0,3$ & $<0,1$ & $>0,4$ & $>0,2$ \\
\hline Thermal & $>1,0$ & $>1,0$ & $<0,75$ & $<1,0$ & $<0,3$ & $<0,1$ & $>0,4$ & $>0,2$ \\
\hline Arching & $>0,1$ to $<1,0$ & $>0,01$ to $<1,0$ & $>0,75$ & $>1,0$ & $>0,3$ & $>0,1$ & $<0,4$ & $<0,2$ \\
\hline
\end{tabular}

Table 2 Comparison between proportions and types of breakdowns for Roger method

\begin{tabular}{|c|c|c|}
\hline $\begin{array}{c}\text { Type of } \\
\text { Breakdown }\end{array}$ & $\begin{array}{c}\text { Proportion } 1\left(\mathrm{P}_{1}\right) \\
\mathrm{CH}_{4} / \mathrm{H}_{2}\end{array}$ & $\begin{array}{c}\text { Proportion 2 }\left(\mathrm{P}_{2}\right) \\
\mathrm{C}_{2} \mathrm{H}_{2} / \mathrm{C}_{2} \mathrm{H}_{4}\end{array}$ \\
\hline Normal Unit & $>0,1$ to $<1,0$ & $<1,0$ \\
\hline Partial Discharge & $<1,0$ & $<1,0$ \\
\hline Arcing & $>0,1$ to $<1,0$ & $>0,1$ to $<3,0$ \\
\hline Low Temperature Thermal & $>0,1$ to $<1,0$ & $<1,0$ \\
\hline Thermal $<700^{\circ} \mathrm{C}$ & $>0,1$ & $<1,0$ \\
\hline Thermal $>700^{\circ} \mathrm{C}$ & $>0,1$ & $<1,0$ \\
\hline
\end{tabular}

\subsubsection{Roger proportion method}

This proportion method also follows the same principle as Doernenburg method. Only proportions $\mathrm{P}_{1}$, proportion $\mathrm{P}_{2}$, and proportion $\mathrm{P}_{5}$ are used. Roger method is divided into more breakdown categories than Doernenburg method and gives more detailed version of fault. This method is also valid to both dissolved gases in oil and gases from gas space. Tab. 2 describes the value 
of proportion corresponding to suggested breakdown diagnoses.

\section{Analysis of natural palm oil results as dielectric liquid 3.1 Dielectric dissipation factor results}

Fig. 12 shows the dielectric dissipation factor resulting from the experiment managed. A low value of dielectric dissipation factor means that the material is a good insulation
Results indicate that the mineral oil, CP6, CP8 and CP10 have low dielectric dissipation factor and are appropriate for high voltage insulation purposes. CPO has the highest dielectric dissipation factor which is 0,012 followed by RPO which is 0,0114 . Both patterns of oil derivatives are not appropriate to be used as high voltage insulation owing to their higher value of dielectric dissipation factor which will decrease the oil resistivity.
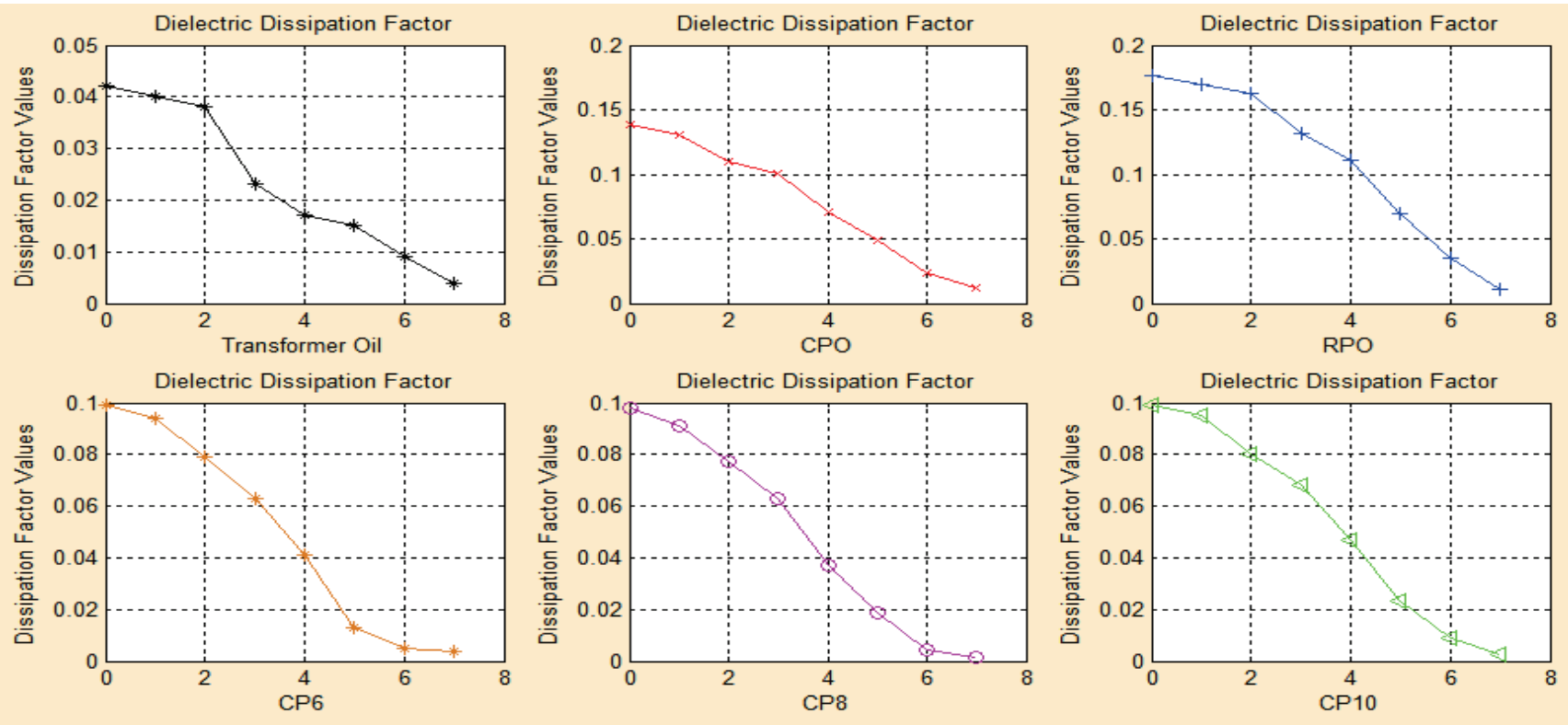

Figure 12 Dielectric dissipation factor values in oil patterns

\subsection{Electrical breakdown voltage results}

The graph in Fig. 13 illustrates the results of electrical breakdown voltage for all patterns tested. Palm oil patterns illustrate the higher value of breakdown voltage as compared to the mineral oil. The CP10 have the highest breakdown voltage level which is $51,64 \mathrm{kV}$ followed by CP8 which is $40,13 \mathrm{kV}$ and CP6 which is
$32,27 \mathrm{kV}$. The potential of palm oil so as to be considered as the good dielectric insulation is based upon the fatty acids included in the oil. For CP10, CP8 and CP6 the fatty acid is less than for the ingenuous palm oil. This is owing to the fractionation process being managed to generate CP10, CP8 and CP6 which decreases the contents of fatty acids in the oil.
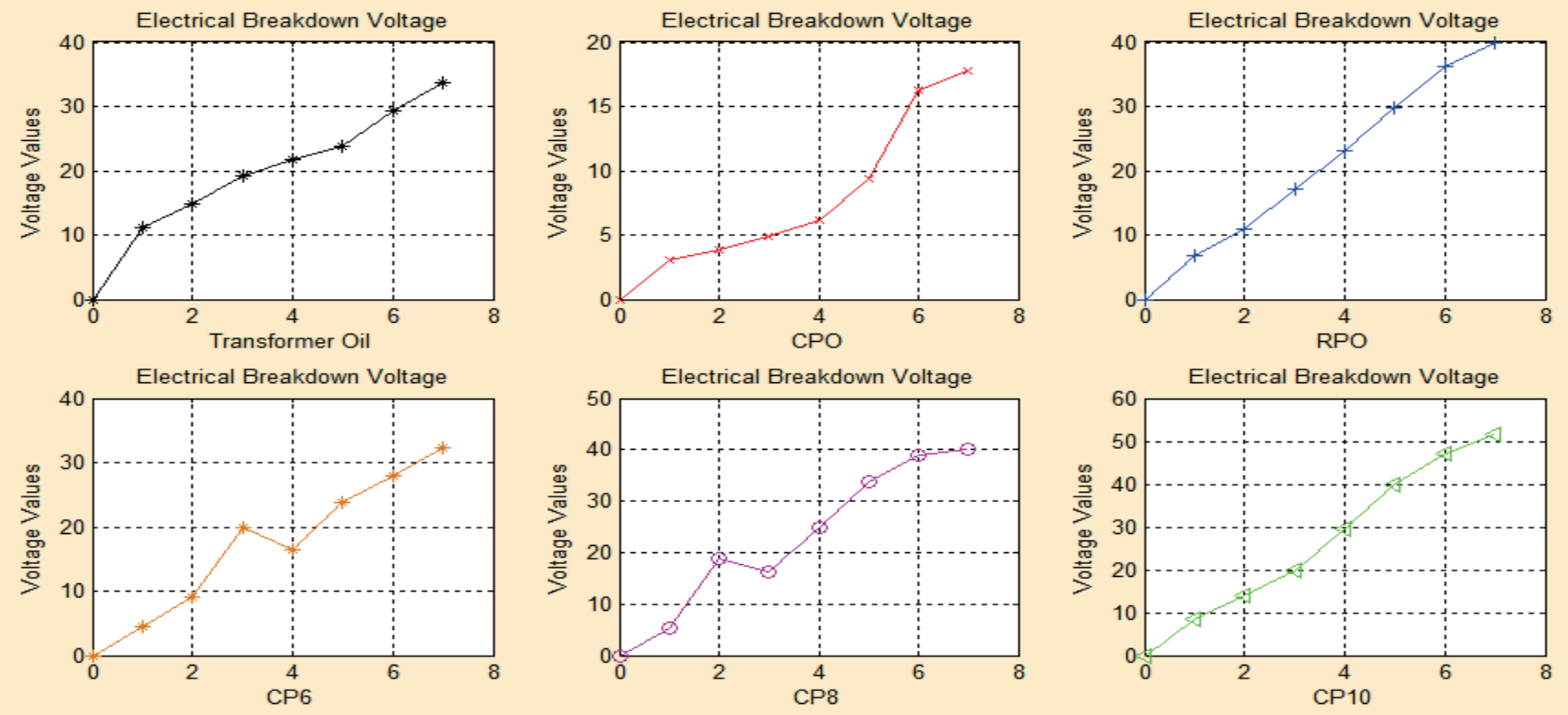

Figure 13 Electrical breakdown voltage values in oil patterns 


\subsection{Interfacial tension results}

Fig. 14 illustrates the oil pattern interfacial tension as a function of temperature. While the power transformer oil is slightly different, all the palm oil patterns indicate the positive value of temperature.
When making a comparison to the standard value, the admissible border in positive value with limit up to 23. So, all patterns of palm oil and its derivatives are ingenuous and have not yet further chemical duration to become insulation oil.
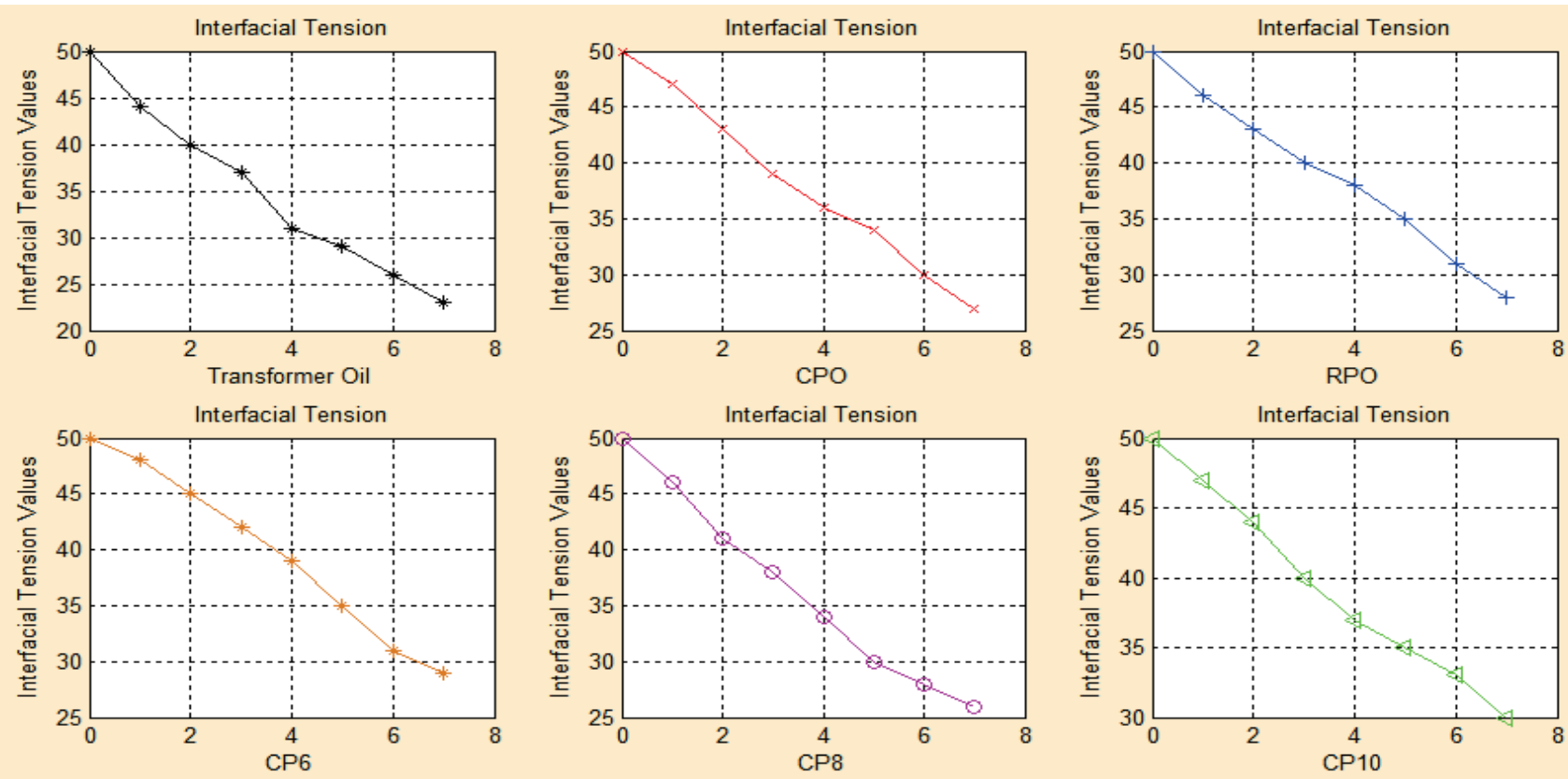

Figure 14 Interfacial tension values in oil patterns

\subsection{Kinematic viscosity results}

Fig. 15 and Fig. 16 illustrate the effect of temperature on the viscosities of palm oil and its derivatives compared to power transformer oil at $40^{\circ} \mathrm{C}$ and $100{ }^{\circ} \mathrm{C}$ respectively. The high value of kinematic viscosity is not appropriate to be used as insulation because the resistance of oil to flow is high. Therefore, it cannot transfer heat properly. At 40 ${ }^{\circ} \mathrm{C}$ the kinematic viscosity of $\mathrm{CPO}$ is the greatest value, followed by RPO, then power transformer oil, and the least value of $\mathrm{CP} 6, \mathrm{CP} 8, \mathrm{CP} 10$ respectively. At $100{ }^{\circ} \mathrm{C}$, these viscosities are decreasing to the lower value below 12 cSt respectively. Oil patterns of CP6, CP8 and CP10 appropriate use as new insulation power transformer. Besides, it can be seen that viscosity diminishes nonlinearly with rising temperature. $\mathrm{CP} 6, \mathrm{CP} 8$ and $\mathrm{CP} 10$ are not always similar value for both temperatures $40{ }^{\circ} \mathrm{C}$ and $100^{\circ} \mathrm{C}$.
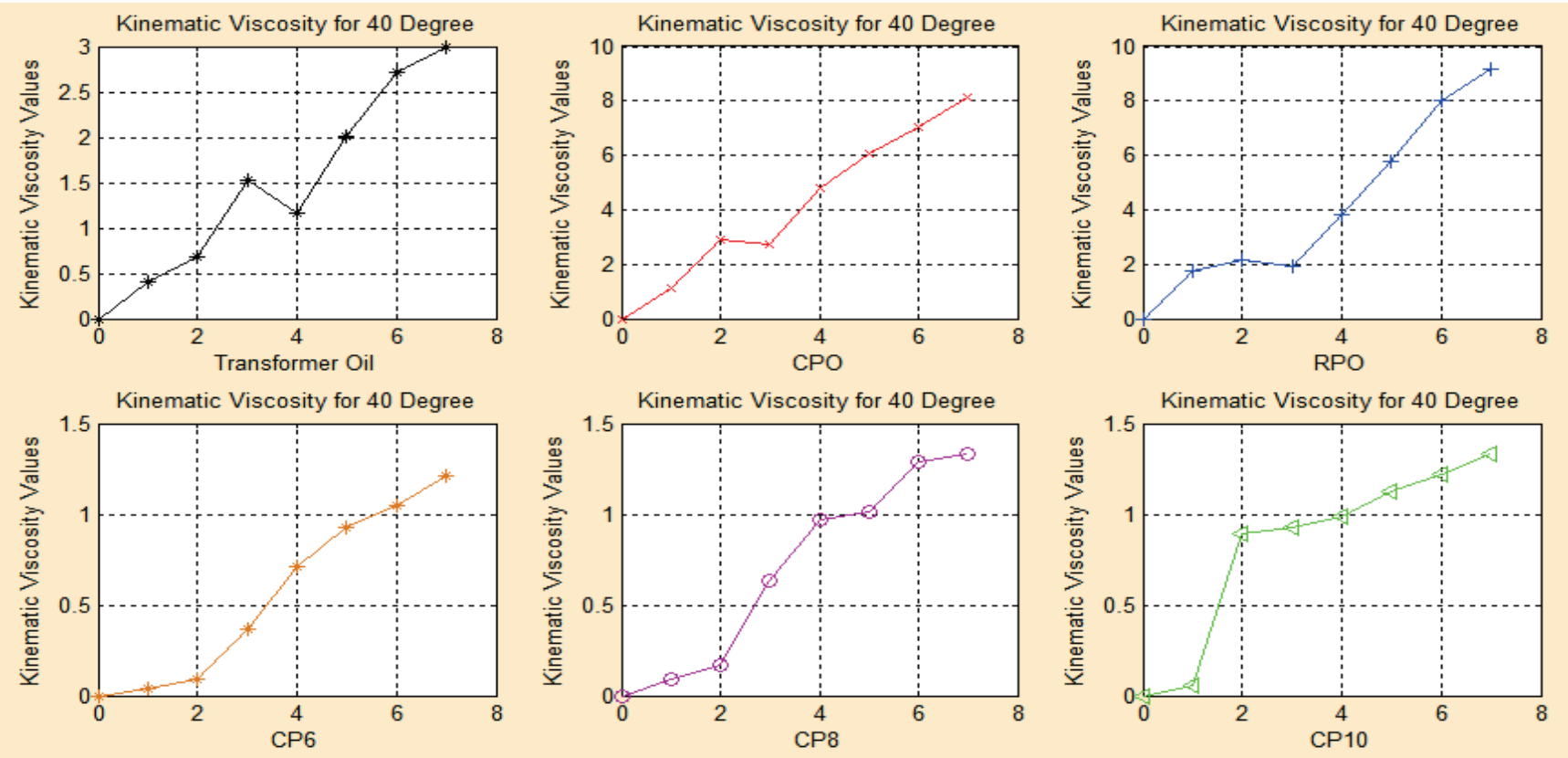

Figure 15 Kinematic viscosity values in oil patterns for $40^{\circ} \mathrm{C}$ 

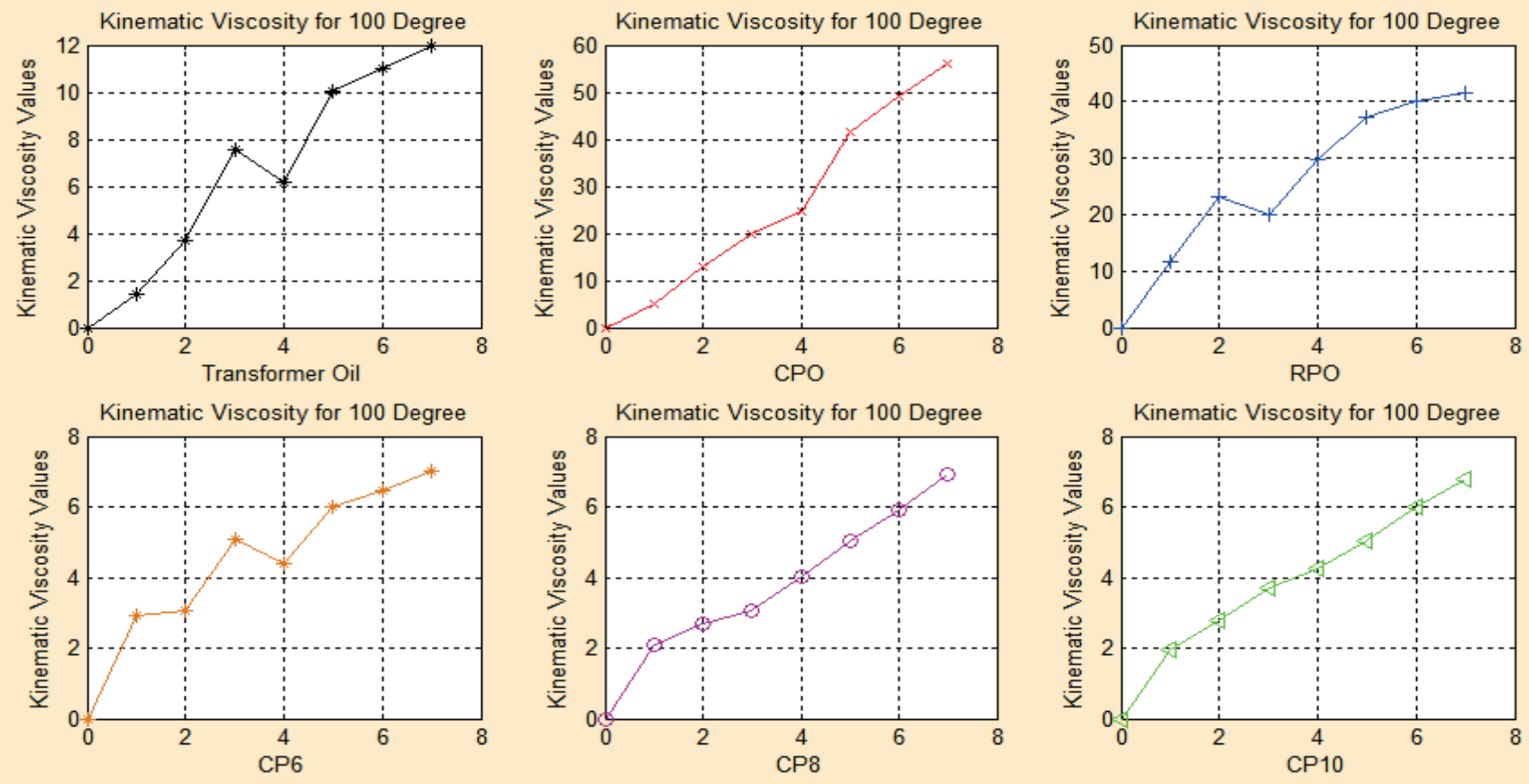

Figure 16 Kinematic viscosity values in oil patterns for $100^{\circ} \mathrm{C}$

\subsection{Density results}

Density characteristics will detect the purity and buoyancy of material. To be as new power transformer oil the density of oil should be between 0.88 and 0.89 and it will be represented in $\mathrm{kg} / \mathrm{cm}^{3}$ unit.
CPO and RPO patterns illustrate the over limit of their density value. Nevertheless, the CP6, CP8 and CP10 illustrate the good result for power transformer oil and accomplish the requirement standard to be new insulation power transformer.
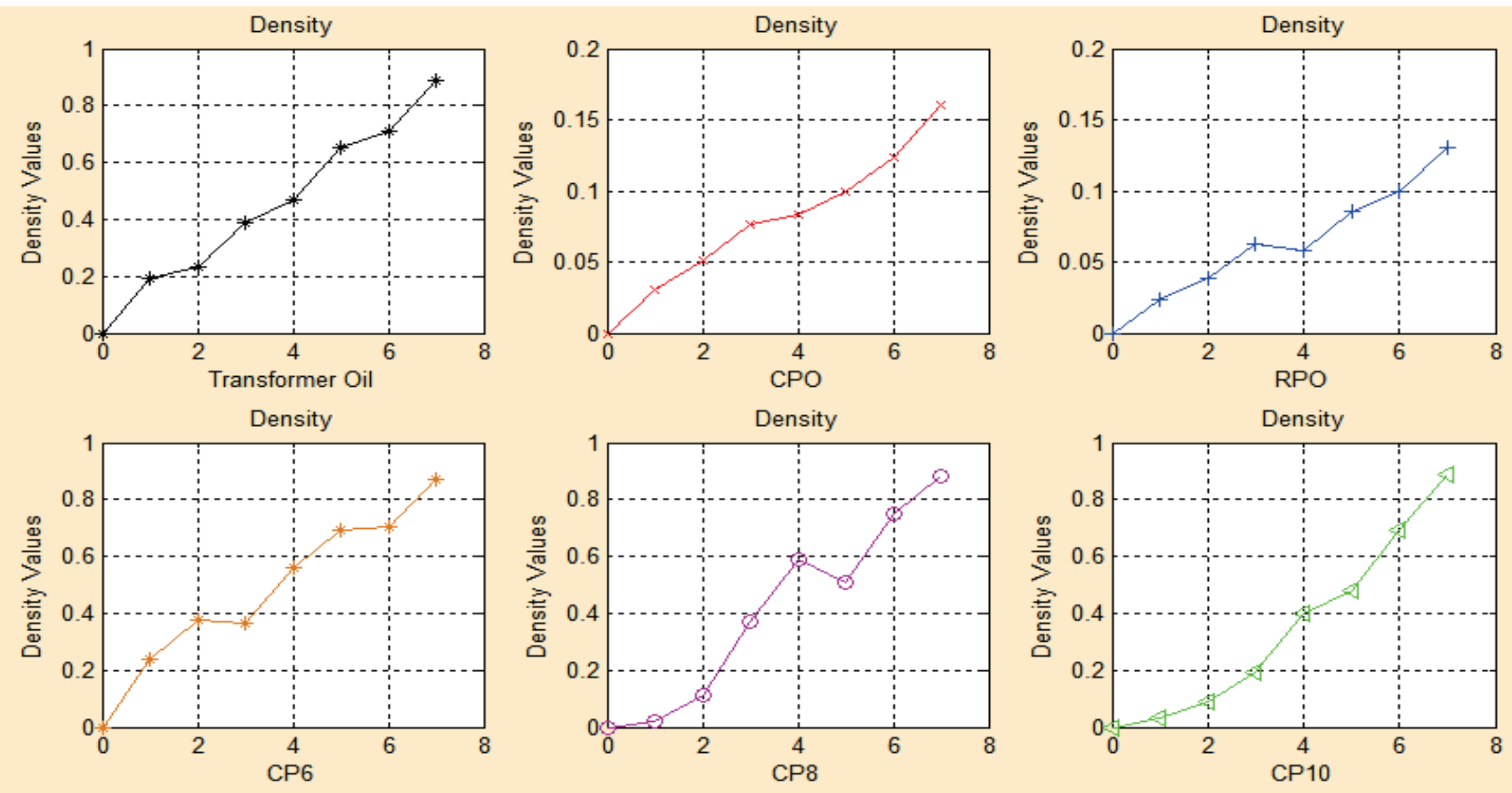

Figure 17 Density values in oil patterns

\subsection{Flash point results}

Fig. 18 illustrates the flash point for power transformer oil patterns as function of temperature. For good insulation, power transformer oil must accomplish the admissible value that is at the temperature range from $140{ }^{\circ} \mathrm{C}$ to $300^{\circ} \mathrm{C}[15]$.
All patterns have high flash point compared to power transformer oil. It is possible to be as power system insulation oil since there have high flash point but some of patterns already pass over the limit given for example CP6, CP8 and CP10. While the CPO and RPO in the range standard. 

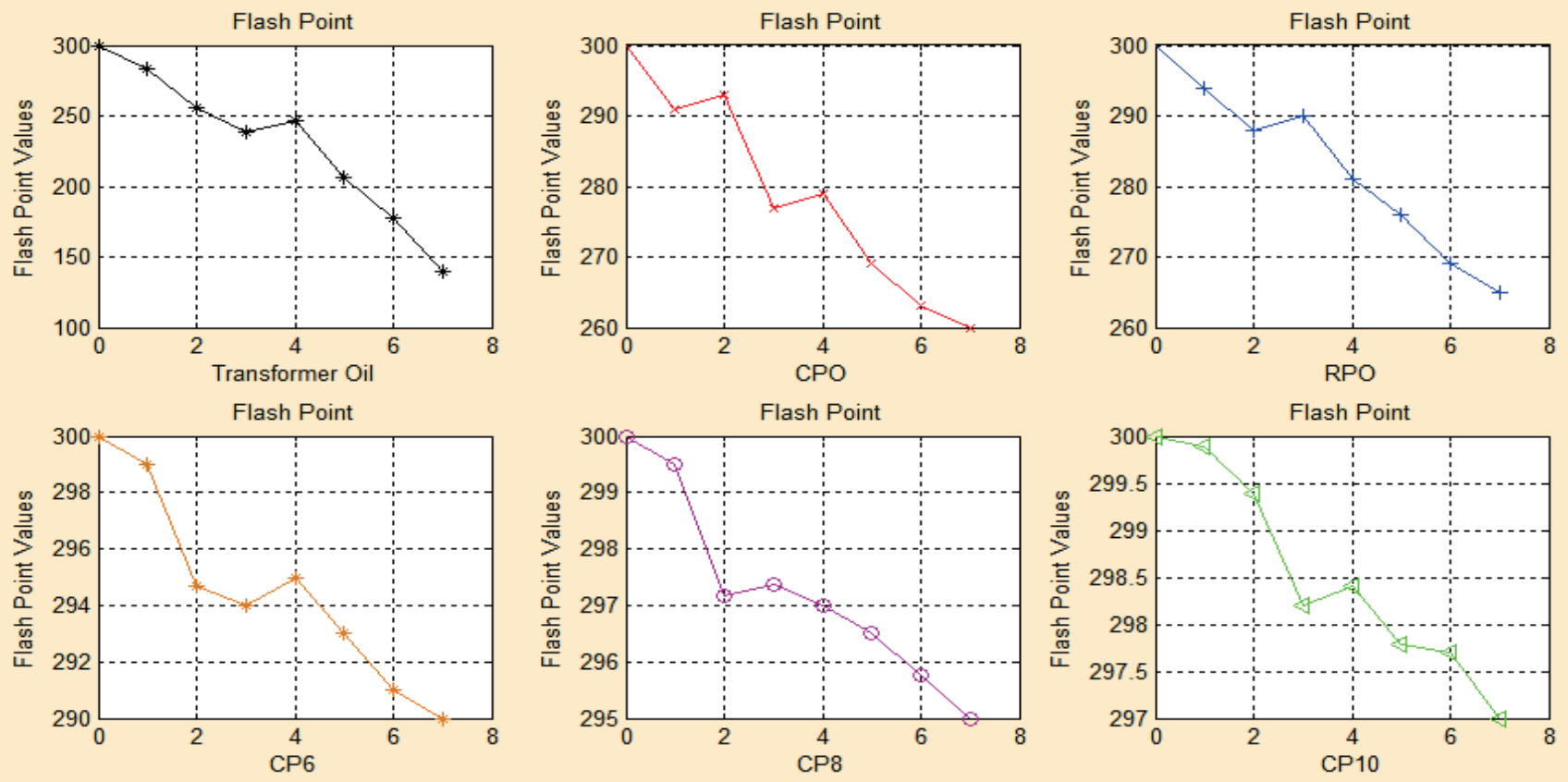

Figure 18 Flash point values in oil patterns

\subsection{Water content results}

Water content for power transformer oil patterns illustrates in part per million (ppm). Water content can be changes from time to time and it's under monitoring part.
Water content can be measured by using "Gas Chromatography Unit" to test Dissolved Gas Analysis (DGA). Fig. 19 shows that $\mathrm{CPO}$ has the highest water content with 90 ppm but in contrast CP10 shows only 27 ppm.
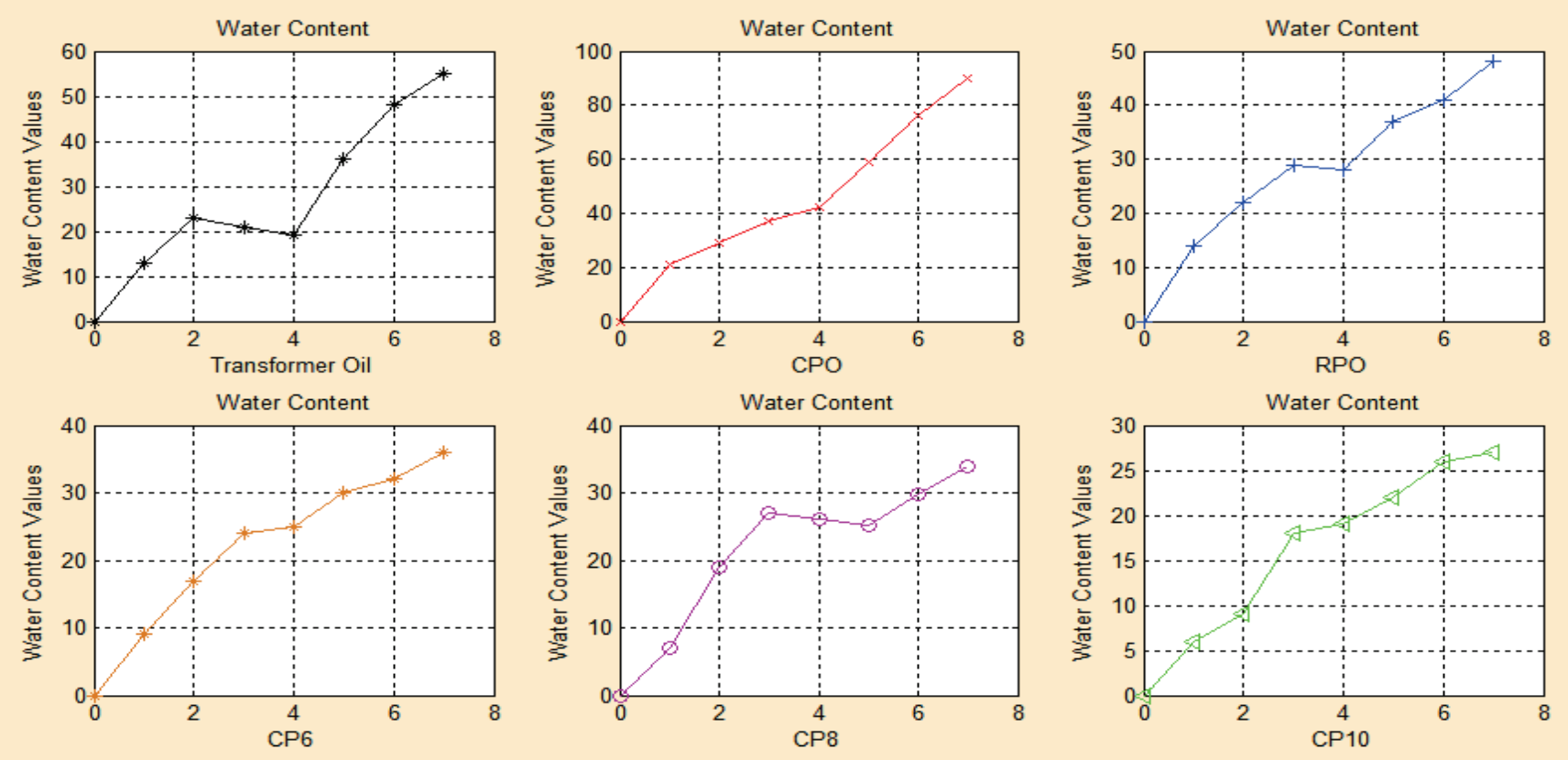

Figure 19 Water content values in oil patterns

\subsection{Dissolved gases analysis results}

In dissolved gas analysis, the IEC codes have been used for several decades and important experience has gathered the whole world to diagnose incipient breakdowns in power transformers. Another relevant interpretation is the analysis of the high level of correct diagnoses obtained by Doernenburg method. The Doernenburg method, as already mentioned, identifies normality situations through no validity of the method. When a threshold of generated gases is not reached, the method will supply a normal diagnostic. It is significant to accentuate that in approximately $13 \%$ of the patterns that presented faults, the Doernenburg method identified only $20 \%$ of them, a violent technical error, illustrating that the equipment is normal, when it essentially presents breakdowns. Tab. 3 shows the pure gases content in the oil patterns. Based upon the conducted experiment all the patterns are below the standard warning of the gases content to be insulation power transformer. 
Table 3 Dissolved gases analysis in oil patterns

\begin{tabular}{|c|c|c|c|c|c|c|c|}
\hline Type of gases & Standard limit value & Transformer oil & $\mathrm{CPO}$ & RPO & CP6 & CP8 & CP10 \\
\hline Hydrogen $\left(\mathrm{H}_{2}\right)$ & $<700$ & $<5$ & 9 & $<5$ & $<5$ & $<5$ & $<5$ \\
\hline Carbon monoxide $(\mathrm{CO})$ & $<350$ & $<1$ & 7 & 3 & 5 & 6 & 2 \\
\hline Carbon dioxide $\left(\mathrm{CO}_{2}\right)$ & $<4000$ & 417 & 1469 & 398 & 452 & 514 & 341 \\
\hline Ethane $\left(\mathrm{C}_{2} \mathrm{H}_{6}\right)$ & $<100$ & $<1$ & 8 & 3 & 4 & 2 & 5 \\
\hline Methane $\left(\mathrm{CH}_{4}\right)$ & $<400$ & 6 & 4 & 2 & 4 & 1 & 2 \\
\hline Ethylene $\left(\mathrm{C}_{2} \mathrm{H}_{4}\right)$ & $<100$ & 2 & 3 & 2 & 2 & 3 & 6 \\
\hline Acetylene $\left(\mathrm{C}_{2} \mathrm{H}_{2}\right)$ & $<5$ & $<1$ & $<1$ & $<1$ & $<1$ & $<1$ & $<1$ \\
\hline
\end{tabular}

\section{Conclusion}

Nowadays the world is witnessing the time of changing from the consuming and environmentally hostile petroleum and mineral oils used in power transformer cooling to palm oils that are renewable and environmentally friendly. These renewable sources have good dielectric characteristics and are suitable for use without any risk. The market and compensatory compressions to decline responsibility risk exposure of mineral oil filled distribution and power transformers are rising. Additionally, there are demands to develop equipment performances and accept more earth amicable options in our power system. The author investigated chemical and electrical characteristics of natural palm oil and its derivatives to be proposed as new insulation power transformer. The results indicated that CP6, CP8 and $\mathrm{CP} 10$ could be considered as insulating materials in the future. Besides, both of these patterns illustrate good characteristics compared to existing mineral oils. Further investigations are needed related long term characteristics and the capability to be amicable to our environment.

\section{Acknowledgements}

The author is pleased to thank the Turkish Electricity Transmission Company for its cooperation in this research work. Valuable discussions about properties and processing of power system equipment palm oil tests were performed with Mr. Senol Ince from High Voltage Test Laboratory in TEIAS. The author also wants to express many thanks to Mr. Hakan Nafiz Ozsoy and Mr. Turgut Kaya for very significant contributions to his work.

\section{References}

[1] Ingebrigtsen, S. et al. Solubility of Carboxylic Acids in Paper (Kraft)-oil Insulation Systems. // 2004 Annual Report Conference on Electrical Insulation and Dielectric Phenomena, 2004, pp. 253-257. DOl: 10.1109/ceidp.2004.1364236

[2] Kuen, C. Analysis and Comparison of Aging Trends of Cellulose for Transformer with Oil-Cellulose-Insulation. // IEEE-978-1-4244-8286-3, International Conference on High Voltage Engineering and Application, 2010, pp. 156163.

[3] Pamuk, N. Investigation of the Long Term Degradation of Cellulosic Insulating Materials in High Voltage Power Transformer. // Journal of Optoelectronics and Advanced Materials. 16, 3-4(2014), pp. 422-428.

[4] Soares, S.; Ricardo, N.; Heatly, F.; Rodrigues, E. Low Temperature Thermal Degradation of Cellulosic Insulating Paper in Air and Transformer Oil. // Society of Chemical Industry. Polym. Int., 50, 3(2001), pp. 303-308. DOI: $10.1002 /$ pi.625
[5] Wilson, A.; Heywood, R.; Lapworth, J. Assessing Dryness of Power Transformers within the Context of Life Management. // Proceedings of the Eighty Annual International Conference of Doble Clients, 2013, Sec. T-3.

[6] Griffin, P.; Lewand, L.; Heywood, R.; Lapworth, J. Gassing Characteristics of Transformer Oils at Modest Temperatures Part I: Transformer Experiences. // Doble Conference, Boston, USA, 2004, pp. 43-51.

[7] Najdenkoski, K.; Rafajlovski, G.; Dimcev, V. Thermal Aging of Distributions Transformers. // IEEE-1-4244-12986/07, IEEE Power Engineering Society General Meeting, 2007, pp. 321-328.

[8] Sundkvist, K. Oil Dependent Gas Formation in Transformer Oil. // Naphthenics. 1, 1(2002), pp. 10-16.

[9] Nynas. Transformer Oil Handbook. Stockholm, Sweden, 2010.

[10] Pamuk, N. Statistical Analysis of Electrical and Mechanical Breakdown Stress for Insulation Performance in High Voltage Power Transformer. // Tehnicki vjesnik-Technical Gazette. 21, 3(2014), pp. 495-503.

[11] IEEE Standard C57.91. IEEE Guide for Loading MineralOil-Immersed Transformers, 1995.

[12] IEEE Standard C57.104. IEEE Guide for the Interpretation of Gases Generated in Oil-Immersed Transformers, 2008.

[13] IEC 60296 International Standards. Fluids for Electro technical Applications-Unused Mineral Insulating Oils for Transformers and Switchgears, 2003.

[14] Hohlein, I. Unusual Cases of Gassing in Transformer Service. // IEEE Electrical Insulation Magazine. 22, 1(2006), pp. 24-27. DOI: 10.1109/MEl.2006.1618968

[15] Linhjell, D.;Lundgaard, L.; Gafvert, U. Dielectric Response of Mineral Oil Impregnated Cellulose and the Impact of Aging. // IEEE Transactions on Dielectrics and Electrical Insulation. 14, 1(2007), pp. 156-169. DOl: 10.1109/TDEI.2007.302884

\section{Author's address}

Nihat Pamuk, Dr.

Turkish Electricity Transmission Company

Maltepe District, Orhangazi Street, No: 74, 54000 Sakarya, Turkey Phone: +90-264-275-1030-1343

Fax: +90-264-275-9030

E-mail: nihatpamuk@gmail.com 